\title{
CHALLENGES TO THE FOSTERING AND ADOPTION OF MUSLIM CHILDREN IN THE BRITISH CARE SYSTEM
}

\author{
Catherine AL JAWDAH \\ The Islamic College, London, UK \\ badgers24@hotmail.com
}

\begin{abstract}
The number of Muslim foster children coming into care in the UK is increasing; however, the number of Muslim foster carers is not. Should care workers attempt to place Muslim children in Muslim homes? Or - as some have suggested - could this be deleterious to them, or be simply irrelevant? While many Muslim children are in foster care in the UK, there is often insufficient cultural training among workers, and some unfortunate situations have resulted in the suffering or even suicide of Muslim children in care. At the same time, it is not always apparent why there is a lack of Muslim foster carers - is it a religious concern, or due to some other reason? In response to these pressing concerns, this article examines the legal and practical implications of fostering and adoption law and policy in Britain. It includes an examination of the barriers preventing Muslim carers from coming into fostering and adoption, as well as the sensitive issue of caring for mahram and non-mahram children. It also reviews Islamic principles of adoption to determine how religious concerns intersect with the concerns of the state. Ultimately it aims to determine if British law, policies, or social work practices should be revised.
\end{abstract}

KEYWORDS: Islamic law, adoption, fostering, British Muslims, Prevent, UK care system

\section{INTRODUCTION}

The number of Muslim children entering foster care in the United Kingdom has been on the rise. However, little research has been done on their experiences or best practices in placing them. There is a common feeling that there are barriers preventing Muslim carers coming into fostering and adoption, but little evidence is given to show whether these barriers are religious, cultural, situational, or otherwise. It is also not clear what the implications are for Muslim children growing up in the care of non-Muslim families with potentially little or no understanding about the religion or culture of the children they are caring for. All this raises the question: are the needs and wellbeing of Muslim children in the care system really being 
met? If not, in what way does this impact the individual Muslim child growing up in care? And, what can be done about it?

This article will begin to address these questions by analysing British laws, Islamic principles, and British fostering and adoption policies. More specifically, this article will discuss:

a) What is the level of compatibility between UK fostering and adoption laws and policies and Islamic principles?

b) What are the barriers preventing Muslims in the UK from undergoing the assessment process to foster and adopt in the UK?

c) What training is required during the assessment process and post-approval for non-Muslim foster carers and adopters to prepare them to care for Muslim children?

The aim of this study is for findings to feed into a fledgling body of research which eventually will have an impact upon legislators, social work practice, and fostering and adoption policy concerning the care of Muslim children, recruitment practices for Muslim foster carers and adoptive parents, and the training of non-Muslim foster carers and adoptive parents of Muslim children.

\section{THE INCREASE OF MUSLIM CHILDREN COMING INTO THE CARE SYSTEM}

One of the first questions that arises is how many Muslim children there are in the British care system. Since data about children's religion is generally not collected, estimates here are based on ethnic data. Over recent years, there has been an increase of ethnic children coming into care, ${ }^{1}$ with possibly 3000 or more of this group being of the Muslim faith, of whom more than half will have been placed with non-Muslim families. ${ }^{2}$ In the first quarter of 2018 , there was a $17 \%$ increase of unaccompanied asylum-seeking children coming into Britain with a variety of religions, cultures, languages, and trauma. Out of this specific group, at least $64 \%$ are likely to be Muslim, having come from majority Muslim countries. ${ }^{3}$ This group of children must also negotiate the Home Office immigration process which can be lengthy. In recent years, at least three asylum-seeking young people have committed suicide with the anxiety of delayed Home Office immigration status cited as the likely reason. ${ }^{4}$

There was a $2 \%$ increase in all ethnic children coming into care in 2016/2017, making a total of $24 \%$ of all children being fostered of ethnic origins. Therefore out of the reported 52,005 children and young people in placement on 31 March 2017 , roughly 12,481 of these children will be of another ethnic origin. ${ }^{5}$ According to figures acquired by the charity Penny Appeal, of these 12,481 children, over 3,00o are Muslim with more than half these children being placed with non-Muslim families (possibly higher, since many officials do not record a chid's religious affiliation). ${ }^{6}$

As can be seen from the charts, there is a growing trend for local authorities to seek CA89 s31 Care Orders and a falling off of voluntary agreements and placement orders. This 
could be for a number of reasons, but it is likely that s2o voluntary agreements are initially established, and then later become accommodated under interim or full care orders due to child protection risks.

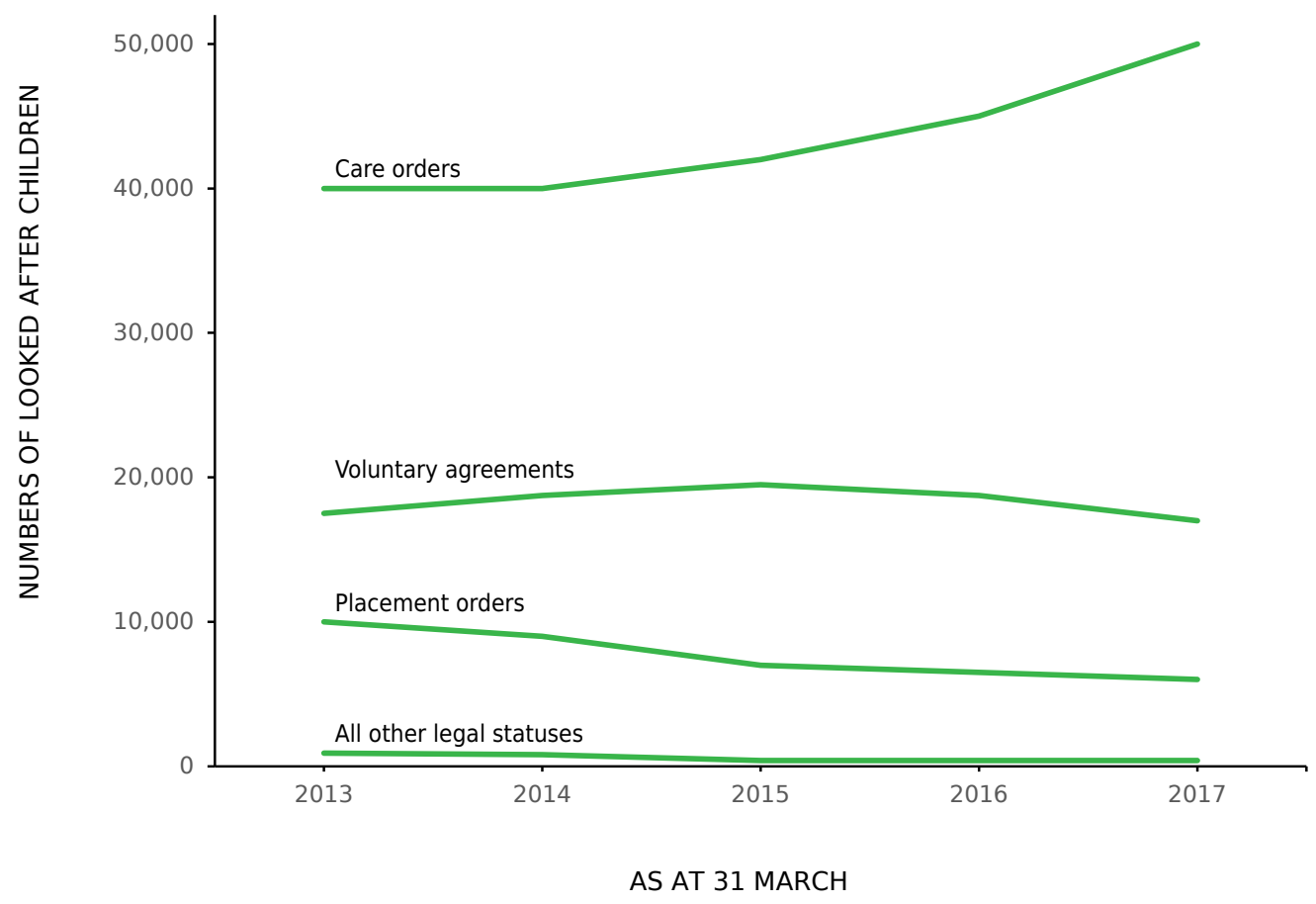

CHART 1: Numbers and proportions of looked-after children at 31 March, by legal status, England, 2013 to $2017 .^{7}$

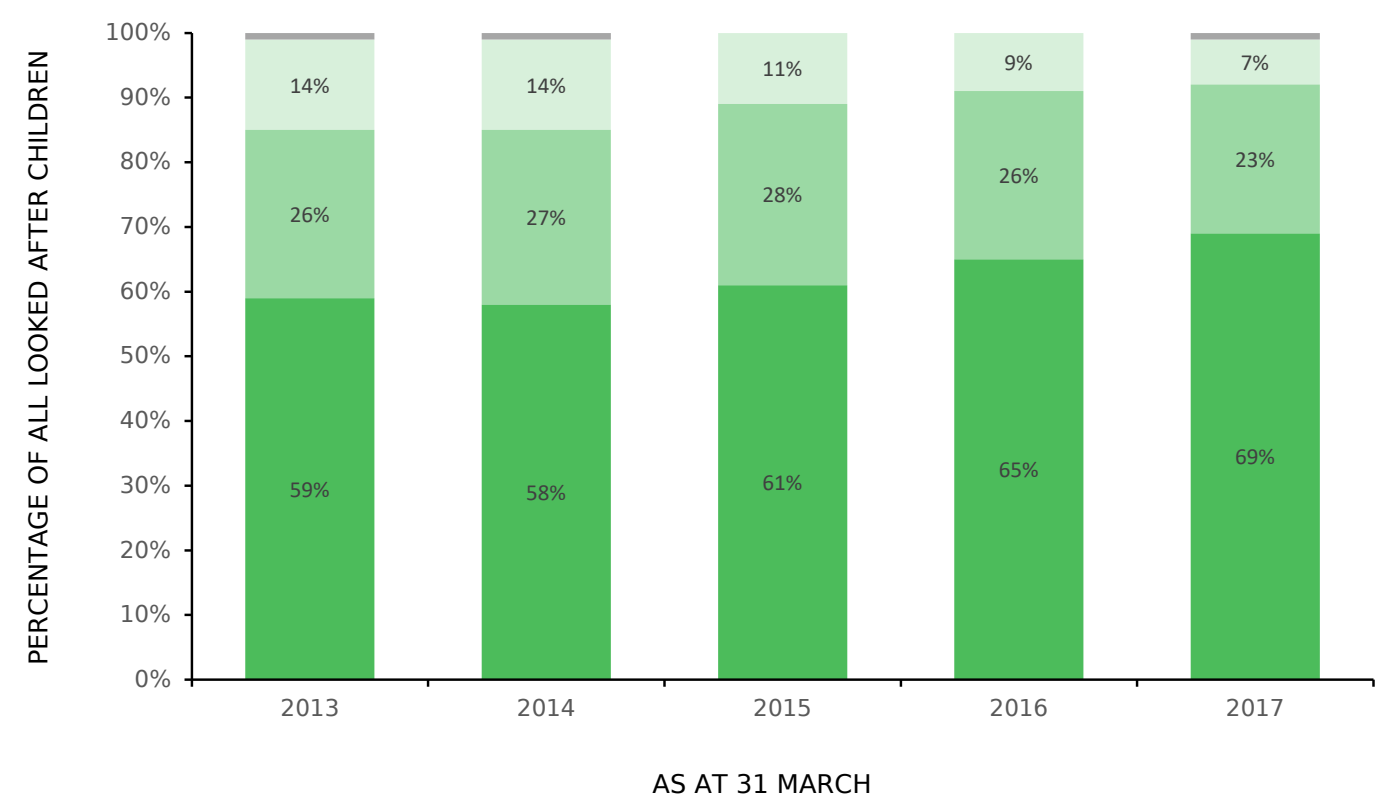

CHART 2: Numbers and proportions of looked-after children at 31 March, by legal status, England, 2013 to $2017 .{ }^{8}$ 
There was a $17 \%$ increase in unaccompanied asylum-seeking children in the first quarter of 2018. ${ }^{9}$ The UK refugee council found that 'Sudan was the top country of origin for the number of unaccompanied children (19\% of all applications in Q1 2018). Eritrea accounted for $14 \%$ of applications, Iraq for $12 \%$, Vietnam for $11 \%$, Afghanistan for $10 \%$, Albania for $10 \%$ and Iran for $9 \%$. Together these seven countries accounted for well over $80 \%$ of all applications in Q1 2018.10 Therefore 64\% of all applications in the first quarter came from predominantly Muslim countries which would equate to approximately 384 children likely to be Muslim coming into the care system in the first quarter of 2018, just from this source. These children likely come with trauma of leaving their homes and families, and incidents of possible abuse during the journey to reach Britain. The children would have the added problem of having different cultures and languages from those of their host families, unless matched to families originating from their country. Referring to the recent suicides of three Eritrean teens, a worker said, 'They feel like they are unwanted. Everything is so different from how they have lived at home. The loneliness, the language barrier; they are placed in accommodation with no one to talk to.' ${ }^{11}$

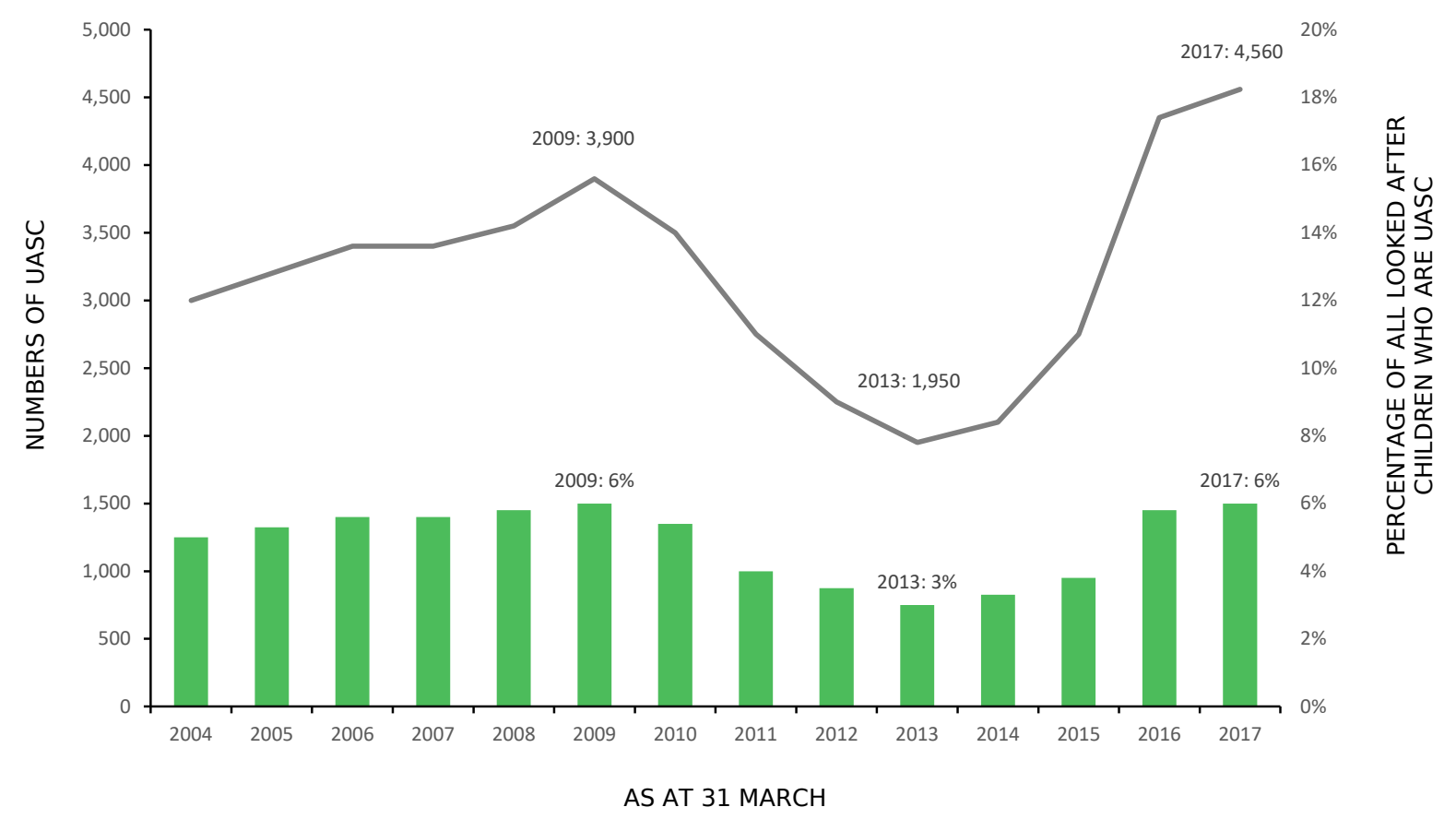

CHART 3: National statistics asylum tables ${ }^{12}$

UASC - Unaccompanied asylum-seeking children.

Despite these numbers, the first Islamic guidance on fostering and adoption in the UK was not published until 2018. ${ }^{13}$ That in itself is arguably an indicator of the paucity of reliable literature available in Britain on Muslim children in care and their carers. ${ }^{14}$ There were virtually no studies on the experiences of Muslim children in foster care prior to the work of S. Cheruvallil-Contractor et al. in 2019, although some work was done by the An Nisa Society in the 199os and, as one author notes, 'one fostering agency, Foster Care Associates, has a specialist project placing Muslim children and recruiting and supporting Muslim foster carers. ${ }^{15}$ 
Therefore, there is a need to examine the situation of Muslim children in foster care in light of both British law and their religious identity. Most of the law relating to the safeguarding and promoting the welfare of children is contained within the Children Act 1989, Guidance and Regulations Volume 4 Fostering Services, the Care Standards Act 2000, the Adoption and Children Act 2002 (and associated regulations), and the Children Act 2004. Along with these pieces of legislation for adoption, there is also the Children and Adoption Act 2006 and associated regulations with the bases stemming from the Local Authority Social Services Act 1970. There is also the United Nations Convention on the Rights of the Child 1989 (UNCRC), which came into force on 15 January 1992, and the contents of which underpin the statutory regulations associated with children's rights and wellbeing and have been implemented through government laws and policies. The UNCRC is a fundamental piece of legislation concerned with children in the care system. ${ }^{16}$ There are regulations contained within the Fostering Services Regulations 2011 and associated National Minimum Standards that provide a clear framework for fostering service providers, foster carers, and associated staff. The repeal of the requirement to match children to families of the same ethnic, cultural, and religious backgrounds was written into the Children and Families Act 2014; this we will return to later.

As shown above, the number of Muslim children coming into care has increased with many unaccompanied asylum-seeking children arriving from war-torn countries to the UK. In most cases, these young people were placed in non-Muslim foster placements, supported lodgings, or unsupported in the community. Many teenage boys in particular, approximately $90 \%,{ }^{17}$ have come into care following long and dangerous journeys, escaping war, famine and often experiencing many forms of abuse along the way. As previously mentioned, $64 \%$ will have come from primarily Islamic countries where the culture also conforms to the observance of Islamic sharica law, which would be present in their mentality, customs, and behaviour. This will impact any non-Muslim British family that fosters or adopts these children. It could also cause issues amongst Muslim foster carers or adopters; indeed, it has been suggested that significant research data shows that outcomes for female Muslim children in foster care with similar cultural backgrounds do better than their male counterparts, who interestingly do not do so well, tending to prefer to prioritise getting on with life as opposed to focussing on their ethnicity. This has led the researchers to question whether boys would be better matched with white foster parents. ${ }^{18}$ This is an important observation and highlights the need for further research into the issue of matching. As Pitcher and Jaffer, writing on the experiences of Muslim foster children, observe, 'Cultural confusion is a common experience among children in foster care. But it can be especially severe for Muslims when their faith, traditional values, and way of life are disrespected and when this is exacerbated by removal from familiar home environments. ${ }^{19}$ Leading on from the subject of matching, the issue of mahram and non-mahram could be an obstacle for prospective Muslim foster carers, adopters, and children placed but this would depend on the level of religiosity of either the family or the child; and although the emphasis has been on the carers, there could be a mismatch for both family and child if the practice of the religion differs. 


\section{SHARI'A CONCERNS OVER GENDER INTERMIXING AND LINEAGE}

According to Islamic law, until the age of puberty, boys and girls not related to the family can live without any restrictions within the family (mahram).$^{20}$ The women of the household and the female girls do not have to wear hijab around the male members of the family whether adult or child. After girls reach puberty, there is a requirement for them to adopt the hijab around any male not closely related to them. In the company of all other nonmahram males which would include foster carers, male birth children, or other non-related male foster children past puberty, the girl would have to wear hijab. Similarly, when Muslim boys reach puberty, the female foster carer, her post-puberty daughters, and any female foster children who had reached puberty would have to wear hijab around the foster boy. The foster carers would have to consider these issues of mahram and non-mahram; respect for the personal privacy of men and women is one of the main concerns. Some Muslims may avoid fostering or adopting children because of this issue. It is at this point, at puberty, that boys (12-15) and girls (9-12) are expected to pray, fast, and adopt hijab around members of the opposite sex who are not birth parents, siblings, cousins, uncle, aunts or grandparents. In Sunni fiqh, girls would be expected to wear hijab around any male not directly related to her once either her pubic hair has grown or her periods have begun. Within the family, non-blood-related males and females should not be alone in a room. As mentioned earlier, depending on the religiosity of the family, this may or may not be an issue within the individual family.

According to Islamic principles, any Muslim child who is adopted into either a Muslim or British family should not take the surname of the adoptive parent, in order to clearly preserve the lineage of both the birth father's name and the adoptive father's name. Sharica-compliant inheritance rules need to be applied when an adoptive parent dies. 'They ask you about orphans: say, "It is good to set things right for them. If you combine their affairs with yours, remember they are your brothers and sisters: God knows those who spoil things and those who improve them. Had He so willed, He could have made you vulnerable too: He is Almighty and Wise"' (Q. 2:220). The Holy Prophet was an orphan and later in life took in and cared for Zayd b. Harith, and brought up his cousin 'Ali b. Abi Talib to ease the hardship on his uncle. As mentioned previously, the Sunna regarding the mixing of non-related males and females should be observed. This has already been discussed in the section on fostering. None of these requirements should be used to discourage or prevent Muslims from fostering or adopting. ${ }^{21}$

Research carried out by Coventry University and the Faith and Peaceful Relations (FPR) Research Group at CTPSR led to a project examining the experiences of Muslim children in the British care system. ${ }^{22}$ Comparing the actual care of Muslim children receiving services from the British Fostering and Adoption Agencies is also very relevant to the question of compatibility with Islamic principles, where Islamically the child and, in particular, the orphan has 20 unalienable rights of care and protection from their guardians. ${ }^{23}$ This will be looked at in more depth. This research is ground-breaking and it has produced several recommendations on Muslim children in the British Care System, one of them supporting a call for all local authorities to record the religion of children and adults in their system, not just ethnicity. 
The Adoption Act 1976 (1) s39 states that the adopted child will be treated in law 'as if he had been born as a child of the marriage (whether or not he was in fact born after the marriage was solemnized)', and paragraph 2 of the same section states, 'An adopted child shall, subject to subsection (3), be treated in law as if he were not the child of any person other than the adopters or adopter.' ${ }^{24}$ In Islamic texts, biological lineage is considered sacred, with every child bestowed the right in Islamic law to know their parents and their ancestry; any negation of this is strongly prohibited by both classical and contemporary scholars and has resulted in the pervasive understanding that adoption is prohibited in Islam. The argument provided by the document produced through Penny Appeal and written by S. Karim (2018) suggests that this is compatible with sharica. He argues:

[I]n terms of understanding the relationship to Tabanni ${ }^{25}$ [they] are 'as if', meaning that there is no denial of lineage, only that the child should be treated equitably with the carer's biological children. Theoretically, these aspects of the law are in line with Islam, which teaches that children who are adopted or in foster care should be treated as well as biological children. ${ }^{26}$

The significant difference between adoption and fostering is that with adoption the birth parents lose parental responsibility which is defined as 'all the rights, duties, powers, responsibilities and authority which by law a parent of a child has in relation to the child and his property'. ${ }^{27}$

However, the changing of adopted children's family and given names are common practice amongst adopters in Britain. Although the courts have made contact arrangements through letter box services for birth families and adopted children, it still rests on cooperation by the adoptive parents and positive representation by the adoptive parents to their adopted child(ren) about their birth parents. "Most children now adopted in England and Wales planned to have some form of contact with members of their birth family...although, in the majority of cases, this is likely to take the form of mediated written exchanges, as opposed to face-to-face meetings. ${ }^{28}$ However, there are adoptive parents who display unwillingness, and on occasion complete refusal, to promote any form of contact between their child and that child's birth family. This is not to say that current adoption practice prevents Muslim families from coming forward to adopt Muslim children but the common practice of issuing new birth certificates without reference to the child's real lineage and a closed mentality to communication about and with birth families may need to be tailored to the needs of Muslim children and not to any adoptive parent, including transracial adopters. This view is supported by Ben Hamida who has stated, 'Adoption is generally frowned on in Muslim culture since the process involves the transfer of parental rights to the adoptive parents. Fostering is however positively encouraged since no similar transfer of parentage occurs. In either case, the surname of the real father should be retained.' ${ }^{29}$ The most significant divergence between British adoption and Islamic principles is, 'Know your genealogy and respect your blood ties. ${ }^{30}$ 


\section{VARIETIES OF BELIEF AND PRACTICE}

To add to the complexities, Islam is a way of life. It encompasses the outlook and functions of the daily life of practising Muslims. The manner in which Islam is practised is not one-dimensional; in fact, there are many contributing layers which make generalisation premature and unethical. Culture and tradition often intertwine with Islamic teachings; thus, the practises of Pakistanis may differ widely from those of Arab, African, or Malaysian Muslims, for example. The differences in Islamic schools of thought also differs to some extent; since the four Sunni schools make up the majority of Muslims, their five pillars of Islam are more widely known, particularly amongst non-Muslims. Ignorance of the various schools of Islamic thought alongside political and religious propaganda could arguably create fear in the worker and prevent them from asking pertinent questions. Similarly, for the same reasons, prospective Muslim foster carers and adopters may also feel reticent to speak about their true religious or cultural principles.

\section{PROTECTION FROM HARM}

When working with Muslims, or any ethnic/religious minority, it is important to have an understanding of theological and cultural differences as well as the similarities, and these must be drawn from life, practical experience, and training in the main tenets of Islam, especially when one considers matching Muslim children with Muslim foster carers and adopters. However, a religious and cultural match cannot be the sole factor either. Children can be kept in a damaging placement due to management's belief that because the ethnic/ religious needs were being met, it was therefore a good arrangement. These aspects were two segments of a whole. Matching is trying to meet the whole child's needs wherever possible: emotional warmth, acceptance, and positive regard are of equal importance.

Religious beliefs and practices are personal matters, and each child and family would have to be matched carefully on these and many other aspects. The skill and knowledge base of assessing fostering/adoption social workers on religious beliefs, cultural practices, and prejudices requires a high level of specific training, without which, the matching of Muslim children to carers can be haphazard at best with a tendency to be blinded by the religious/cultural match, as opposed to the needs of the whole child. The concept of 'Cultural Humility', which is a new approach coming out of America making the client the religious and ethnic 'expert' to the worker, encourages the worker to learn from the client, as they are the expert when it comes to their culture, ethnicity, and religion.

The issue of political correctness around race and ethnicity contributed to the death of Victoria Climbié on 25 February 200o. Victoria was a little girl brought to Britain from the Ivory Coast by her aunt for a better life and who later died in horrific circumstances at the hands of her aunt and partner. The errors made by the professionals who had contact with Victoria during her short life in Britain resulted in an enquiry by Lord Laming and resulted in a raft of legislation and policies in the field of child safeguarding. Indeed, the Laming Report says, 'The basic requirement that children are kept safe is universal and cuts 
across cultural boundaries...Cultural heritage is important to many people, but it cannot take precedence over standards of childcare embodied in the law.' ${ }^{31}$

Few would disagree with this statement when dealing with child protection issues; if a child is being harmed, and under British law is deemed at risk of significant harm, then professionals must protect the child and take the necessary steps to ensure the child's safety, with all other issues taking second place. However, in the case of children being at risk of extremism and professionals being burdened with such decisions that could criminalise families or separate children from their parents, then knowledge of religion and culture and the political context of their country of origin must be taken into account.

Unfortunately, there is no specific research that has dared to take the bull by the horns in the fostering and adoption arena and address these issues, but while acknowledging the risk of appearing biased, there are questions that need to be asked, particularly where the Prevent policies are concerned. To support this stance, a 20 year follow-up from their first published research paper entitled 'Islamophobia', the Runnymede Trust stated, 'As has been repeatedly recommended by academics and by human rights and civil liberties advocates, there needs to be a truly independent inquiry into all aspects of Prevent and its impact on Muslim communities, based on full disclosure by all of the agencies and institutions involved, ensuring an opportunity to hear evidence from all affected communities. ${ }^{32}$

That said, can social workers, carers, and adopters - whose training is often very patchy or even non-existent around the subject of ethnicity, culture, and religion - really be expected to understand the multi-faceted aspects of Islam, culture, similarity, and difference? It is doubtful, although greater emphasis during the education of social workers and foster carers/adopters needs to take place to stimulate a desire to learn more, not just about Islam but the cultures and varying schools of thought within Islam which a child has previously been brought up in. However, the recruitment of more Muslim foster carers and adopters will make the Islamic lifestyle more readily available for Muslim children. It is this immersive lifestyle which cannot be reflected in non-Muslim homes, and this is without criticising the deep commitment of many mainstream fostering and adoptive families.

\section{THE COMPATIBILITY OF ISLAMIC LAW WITH BRITISH FOSTERING AND ADOPTION LAW, POLICIES AND PRACTICE}

This leads to the overarching question of whether there is or can be harmony between British policies and Islamic law. The following table of comparison analyses the compatibility of British law and policy in fostering and adoption vis-à-vis Islamic principles, using data from government legislation, namely: Children Act 1989, Care Standards Act 200o, Children Act Guidance and Regulations Vol. 3 (2010), Fostering Minimum Standards 2011, Adoption Minimum Standards 2011, Adoption Act 1976, Adoption and Children Act 2002 and 2006, and Children Act 2004 with the bases all stemming from the Local Authority Social Services Act 1970 and the United Nations Convention on the Rights of the Child $1989 .{ }^{33}$ The Children and Families Act 2014 was also referred to while compiling the table of legislation and policies. ${ }^{34}$ The Islamic principles were sourced through the Holy Qur'an, hadith, ${ }^{35}$ and Islamic Guidance on Adoption and Fostering 2018. ${ }^{36}$ This area requires more research but that said, 
overall Islamic principles appear to be compatible with British law and policies; however, it could be argued that fostering and kinship care are the best match for Muslim children and families in terms of Islamic principles, as will be discussed..$^{37}$

\begin{tabular}{|c|c|c|}
\hline Islamic Principles & Fostering Laws/Policy & Adoption Laws/Policy \\
\hline $\begin{array}{l}\text { Care for and maintain. } \\
\text { Q2:220 }\end{array}$ & $\begin{array}{l}\text { Children Act } 1989 \text { Guidance } \\
\text { and Regulations Volume 4: } \\
\text { Fostering Services (2011), } \\
\text { Care Standards Act 2000. } \\
\text { UNCRC 1989. Fostering } \\
\text { Services: National Minimum } \\
\text { Standards (2011) Standards } \\
1-12 \text { and 15. Sufficiency: Stat- } \\
\text { utory Guidance on Securing } \\
\text { Sufficient Accommodation for } \\
\text { Looked After Children (2010) }\end{array}$ & $\begin{array}{l}\text { Children Act } 1989 \text { Adoption } \\
\text { and Children Act } 2002 \text { UNCRC } \\
\text { 1989. The Care Planning, } \\
\text { Placement and Case Review } \\
\text { and Fostering Services (Mis- } \\
\text { cellaneous Amendments) } \\
\text { Regulations } 2013 \text { - available. } \\
\text { Adoption National Minimum } \\
\text { Standards (2011) Standards } \\
1-15\end{array}$ \\
\hline $\begin{array}{l}\text { Not to spend orphans' wealth } \\
\text { outside the necessities of life. } \\
\text { Q6:152 }\end{array}$ & $\begin{array}{l}\text { The National Minimum Foster- } \\
\text { ing Allowance and Fostering } \\
\text { Payment Systems: Good Prac- } \\
\text { tice Guidance (2006) }\end{array}$ & $\begin{array}{l}\text { Adoption National Minimum } \\
\text { Standards (2011) Standards } \\
10,11,13 \text { and } 22\end{array}$ \\
\hline $\begin{array}{l}\text { Protect the orphan } \\
\text { Q93:6 and } 9\end{array}$ & $\begin{array}{l}\text { Children Act 1989. UNCRC } \\
\text { 1989. Working Together to } \\
\text { Safeguard Children: A Guide } \\
\text { to Inter-agency Working to } \\
\text { Safeguard and Promote the } \\
\text { Welfare of Children (March } \\
\text { 2015) }\end{array}$ & $\begin{array}{l}\text { Children Act } 1989 \\
\text { UNCRC } 1989 \\
\text { Adoption National Minimum } \\
\text { Standards (2011) Standard } 4 \\
\text { and } 22\end{array}$ \\
\hline $\begin{array}{l}\text { Provide physically, mentally } \\
\text { and emotionally. } \\
\text { Q76:8 }\end{array}$ & $\begin{array}{l}\text { Fostering Services: National } \\
\text { Minimum Standards (2011) } \\
\text { Standards 1-12 and 15 }\end{array}$ & $\begin{array}{l}\text { Adoption National Minimum } \\
\text { Standards (2011) Standards } \\
1-16\end{array}$ \\
\hline $\begin{array}{l}\text { Act as trustees for the or- } \\
\text { phan's wealth and return it to } \\
\text { them intact as adults. } \\
\text { Q18:82 }\end{array}$ & & $\begin{array}{l}\text { Adoption National Minimum } \\
\text { Standards (2011) } \\
\text { Standard } 14 \text { (3) and } 14 \text { (4) }\end{array}$ \\
\hline $\begin{array}{l}\text { Ensure the education of the } \\
\text { orphan academically, morally, } \\
\text { religiously and socially. }\end{array}$ & $\begin{array}{l}\text { Fostering Services: National } \\
\text { Minimum Standards (2011) } \\
\text { Standards 2,3 and 8. Promot- } \\
\text { ing the Education of Looked } \\
\text { After Children: Statutory } \\
\text { Guidance for Local Authorities } \\
\text { (July 2014). }\end{array}$ & $\begin{array}{l}\text { Adoption National Minimum } \\
\text { Standards (2011) Standard } 7\end{array}$ \\
\hline $\begin{array}{l}\text { Honour the orphan. Do not } \\
\text { humiliate, degrade, abuse, hit } \\
\text { or unjustly rebuke an orphan. } \\
\text { Q89:16/17 }\end{array}$ & $\begin{array}{l}\text { Children Act 1989. UNRCR } \\
\text { 1989. Fostering Services: } \\
\text { National Minimum Standards } \\
\text { (2011) Standard } 2 \\
\end{array}$ & $\begin{array}{l}\text { Adoption National Minimum } \\
\text { Standards (2011) Standards } \\
1,2,3,4,5,9 \text { and } 13\end{array}$ \\
\hline $\begin{array}{l}\text { Nurture good intercommu- } \\
\text { nication with the orphan so } \\
\text { they do not feel isolated or } \\
\text { alone and are well socialised. } \\
\text { Q4:36 }\end{array}$ & $\begin{array}{l}\text { Fostering Services: National } \\
\text { Minimum Standards (2011) } \\
\text { Standards 1, 2, } 3 \text { and } 15\end{array}$ & $\begin{array}{l}\text { Adoption National Minimum } \\
\text { Standards (2011) Standards } \\
1-9\end{array}$ \\
\hline
\end{tabular}




\begin{tabular}{|c|c|c|}
\hline $\begin{array}{l}\text { Give sadaqah to orphans - } \\
\text { give charity to them. } \\
\text { Q2:215 }\end{array}$ & & \\
\hline $\begin{array}{l}\text { Give fair and equal treatment } \\
\text { to the orphan alongside oth- } \\
\text { ers. } \\
\text { Q4:127 }\end{array}$ & $\begin{array}{l}\text { Fostering Services: National } \\
\text { Minimum Standards (2011) } \\
\text { Standards 1-12 }\end{array}$ & $\begin{array}{l}\text { Adoption National Minimum } \\
\text { Standards (2011) Standards } \\
1-16\end{array}$ \\
\hline $\begin{array}{l}\text { Teach the orphan to manage } \\
\text { money. Q4:6 }\end{array}$ & $\begin{array}{l}\text { Fostering Services: National } \\
\text { Minimum Standards (2011) } \\
\text { Standard } 12\end{array}$ & $\begin{array}{l}\text { Adoption National Minimum } \\
\text { Standards (2011 }\end{array}$ \\
\hline Freedom of expression & $\begin{array}{l}\text { Fostering Services: National } \\
\text { Minimum Standards (2011) } \\
\text { Standard 1 }\end{array}$ & $\begin{array}{l}\text { Adoption National Minimum } \\
\text { Standards (2011) Standard } 1\end{array}$ \\
\hline $\begin{array}{l}\text { Care for the orphan's health } \\
\text { needs }\end{array}$ & $\begin{array}{l}\text { Promoting the Health and } \\
\text { Wellbeing of Looked After } \\
\text { Children: Statutory Guidance } \\
\text { for Local Authorities, Clinical } \\
\text { Commissioning Groups and } \\
\text { NHS England (March } 2015\end{array}$ & $\begin{array}{l}\text { Adoption National Minimum } \\
\text { Standards (2011) Standard } 5\end{array}$ \\
\hline $\begin{array}{l}\text { Has a role in Islam and the } \\
\text { country's development }\end{array}$ & & \\
\hline $\begin{array}{l}\text { Play and do activities that } \\
\text { they want }\end{array}$ & $\begin{array}{l}\text { Fostering Services: National } \\
\text { Minimum Standards (2011) } \\
\text { Standard } 7\end{array}$ & $\begin{array}{l}\text { Adoption National Minimum } \\
\text { Standards (2011) Standard } 6\end{array}$ \\
\hline $\begin{array}{l}\text { The orphan's status should } \\
\text { be the same in the eyes of } \\
\text { Islamic and national law }\end{array}$ & & \\
\hline $\begin{array}{l}\text { To be provided for until adult- } \\
\text { hood and beyond if unable to } \\
\text { work. }\end{array}$ & $\begin{array}{l}\text { Children Act } 1989 \text { Guidance } \\
\text { and Regulations Volume 3: } \\
\text { Planning Transition to Adult- } \\
\text { hood for Care Leavers (2010) } \\
\text { Fostering Services: National } \\
\text { Minimum Standards (2011) } \\
\text { Standard } 12 \\
\end{array}$ & $\begin{array}{l}\text { Adoption National Minimum } \\
\text { Standards (2011) Standards } \\
1-16\end{array}$ \\
\hline $\begin{array}{l}\text { Protect themselves and } \\
\text { self-defence }\end{array}$ & $\begin{array}{l}\text { Fostering Services: National } \\
\text { Minimum Standards (2011) } \\
\text { Standard } 1 \text { (1.5) } \\
\text { Getting the Best from Com- } \\
\text { plaints: Social Care Com- } \\
\text { plaints and Representations } \\
\text { for Children, Young People } \\
\text { and Others } \\
\text { Voice of the Child in Care. } \\
\end{array}$ & $\begin{array}{l}\text { Adoption National Minimum } \\
\text { Standards (2011) Standard } 22 \\
\text { Child Line }\end{array}$ \\
\hline $\begin{array}{l}\text { The orphan should have their } \\
\text { own privacy. } \\
\text { Q24:27, Q49:12 }\end{array}$ & $\begin{array}{l}\text { Fostering Services: National } \\
\text { Minimum Standards (2011) } \\
\text { Standards 1, } 6 \text { and } 10\end{array}$ & \\
\hline
\end{tabular}

CHART 4: A comparison of the 20 rights of the Muslim orphan with British law, including fostering and adoption regulations ${ }^{38}$

This table of comparison highlights the main rights of orphaned/fostered/adopted children in Islam and in Britain, as covered in the laws and policies. There is a clear indication that many aspects of Islamic sharica law concerning the care of orphans are present in the 
fostering and adoption laws and policies of Britain. It would indicate that apart from the issue of changing an adopted child's name, both forms of care for orphaned children in Britain are acceptable within Islamic principles. Indeed, it has been argued that Q4:127, which requests Muslims to treat orphans in a fair and equal manner to others, could be used to argue the case for a change of the child's name to that of his/her adoptive family. Muslim scholars appear to fall into two schools of thought on this subject. The first is that if a woman is allowed to change her family name to that of her husband and it does not affect lineage but rather is just for identification purposes, then it is acceptable for an orphaned child to take his adoptive father's name. The second, if it is not allowed for a woman to change her name to preserve her lineage, then it is not acceptable for an orphaned child either. ${ }^{39}$

Other scholars find it permissible for a Muslim woman to change her name to that of her husband because it does not cause lineal confusion; whereas, in the case of an orphaned child it does, therefore it is not permissible. So, the position of Muslim scholars is not clear. However, the majority do agree on a hyphenated name which contains the child's biological lineage and the new adoptive father's name, e.g. Ahmad Rizvi-Khan. It is worth noting that even though a new birth certificate is issued upon the adoption of a child, the original one is stored safely and can be accessed by the child once he/she has reached 18 years of age. ${ }^{40}$ Under exceptional situations, most scholars agree it is acceptable to change the child's name if that child would be at risk of significant harm should they be tracked down through their original name. ${ }^{41}$

Under the Adoption Minimum Standards, it is not a given that the adopted child will receive their own bedroom; they may have to share with another child or children. Depending on the age of the child and their assessed needs, this may not be a problem Islamically because small children are not subject to non-mahram restrictions and could feel comforted having another child in the room at night. However, the child does have the right to express his/ her feelings and within this their preferences could be ascertained. ${ }^{42}$ In the case of siblings, providing the assessment has not uncovered any risks to a shared bedroom arrangement, then depending on age and gender it would also be Islamically acceptable.

Giving șadaqa to orphans is a Muslim's responsibility and second only to providing for the needs of poor relatives and family. Sadaqa is the Arabic term for charity; therefore, members of the Muslim community are duty-bound to provide for and support orphans. There is no direct parallel in British law or policy on this aspect of fostering or adoption. However, there are charities within the British community that support children in care to compensate the acknowledged disadvantages of being a child looked after. Some of the main charities are: The Children's Society, NSPCC, Barnardo's, Action for Children, Become and Catch 22 (charities specifically for children in care), Voice of the Child in Care, and Muslim Fostering. There, this element of șadaqa could be said to be met outside of statutory provision but met nonetheless.

Another area where there is no provision under British fostering or adoption law or policies is the requirement for the orphan to be included and given opportunities for involvement in their religion and their country's development. Although there is mention of individualised care in Standard 2 (2.1) Fostering National Minimum Standards 2011, the promotion of religious beliefs is not specifically mentioned: 'Children are provided with personalised care that meets their needs and promotes all aspects of their individual 
identity. ${ }^{43}$ The problem with this aspect of the minimum standards for both fostering and adoption is that most local authorities do not record a child's religion. This has been taken up with local authorities by 'Muslim Foster Network', a Bradford-based charity who work to enhance awareness within local authorities and independent fostering agencies to look after the needs of Muslim children and provide training to non-Muslim foster carers looking after Muslim children. ${ }^{44}$

\section{DOES THE ASSESSMENT PROCESS FOR FOSTER CARERS AND ADOPTERS CREATE BARRIERS FOR MUSLIM CARERS?}

The preceding sections indicate that there is a high level of compatibility between Islamic principles and British law. Contrary to some popular assumptions, sharica is not a barrier for Muslims to adopt. However, the factors preventing Muslim families coming forward to care for Muslim children are not just religious in nature. Studies on poverty within the Muslim community by the Runneymede Trust provide a clearer insight into understanding the barriers faced by Muslims. ${ }^{45}$ Alongside this is the rise of Islamophobia since 2001 and the introduction of the Prevent legislation. ${ }^{46}$ Here, it will be useful to employ Critical Race Theory which has recently been used in research into educational attainment in BAME (black, Asian, and mixed ethnicity) children. ${ }^{47}$ This theory can be applied to Muslim children and families in care proceedings and the assessment and support of prospective Muslim foster carers and adopters. Indeed, there is a need for further research into the needs of Muslim children in the care system; whether matching is as important for Muslim children as we think it may be; how Islamophobia and the Prevent agenda are affecting Muslims, and in particular Muslim children in care and their carers; the 'othering' of Muslims in general; and the establishment's blindness to the violent doctrines within Wahhabism around the world and in particular, in Britain.

Also of interest in transracial fostering and adoption is the current government Prevent agenda and the effects of this on all Muslim children but in particular hugely vulnerable children in fostered and adoptive families, especially if those families are non-Muslim. Indeed following the incidence of two unaccompanied child asylum-seekers; one who posted ISIS propaganda on Facebook and another teenager from Iraq living in foster care who was involved in the Parsons Green Tube bombing, an article was printed in the Telegraph in which 'a leading adoption charity is urging the government to train foster carers to spot the signs of radicalisation among young asylum-seekers from countries like Syria and Iraq who are living in their homes'; ${ }^{48}$ with several unaccompanied children in care having committed suicide in 2017. ${ }^{49}$ The lack of hard data to understand Muslim children's experiences of the care system in Britain is now desperate and for these particular children the impact of Home Office procedures, in terms of lengthy waiting times for 'leave to stay' decisions, must be added to the equation.

The Fostering Network teamed up with Mercy Mission UK in 2017 in a project which focussed on the links (or lack) between the Muslim faith and fostering in order to inform and support fostering services across England to reflect and better meet the cultural needs 
of the children they care for. Their findings were published in 2019, supporting the view that the mandatory recording of religion by all children's service providers was needed.

Studies by the Fostering Network, Coventry University and another by Pitchler and Jaffar (2018) are the first of their kind to focus on Muslims in Britain, either of Muslim children in foster care or waiting to be adopted, and the families /individuals, either proposing to or who are already caring for them. Research into ethnic foster carers and adopters already informs us that this group is faced with more barriers than their white contemporaries, and discussions with Muslim Foster Network revealed some areas that they have identified regarding Muslim and ethnic fostering. In particular, it points to a lack of training of white carers, which the Muslim Fostering Network is trying to meet through offering courses to Local Authority and Independent Fostering Agencies nationwide and promoting a knowledgeable approach to prospective Muslim families coming forward wishing to foster. ${ }^{50}$ The Muslim Foster Network also listed similar barriers of Muslim families being larger than white ones with a culture of sharing bedrooms. Speaking to the Muslim Foster Project, they informed me that Somali families, in particular, think in terms of spare bed, not spare room. The local authorities were found not to be consistent regarding their bedroom sharing policies, with some allowing siblings to share until the age of 5 , others insisting on separate bedrooms after 9 or 10, and others allowing bedroom sharing throughout a child's childhood. ${ }^{51}$ Interestingly, the Muslim Foster Network found it extremely difficult to access local authority fostering services. The Charity experienced a pervasive resistance from local authorities to commence a dialogue about Muslim children in foster care and the need for Muslim foster carers and more specific training of non-Muslim carers looking after Muslim children. I was advised that it took a year for the charity to get their own local authority in Bolton to begin a dialogue.

This resistance to developing a more open-minded view was reflected in research carried out by Oxford University, and as part of their recommendations stated: 'Fostering service providers should adopt more flexible and open approaches to selection in order to reduce bias against specific groups. The use of standardised selection instruments may have a role within the process in doing this. In applying instruments, use should be made of local community knowledge to address cultural issues. For example, poverty should not be conflated with lack of capacity to provide good quality care. ${ }^{52}$

There are many areas of the process which could negatively impact potential Muslim and ethnic families coming forward to foster or adopt. Literacy in the English language could have a huge impact on the assessment process, particularly for fostering. Fostering in twenty-first century Britain is a professional occupation. ${ }^{53}$ It involves a high level of literacy in order to comply with the safe care of both the child(ren) and carers. Communication is key to the fostering role, and the ability to work in a multi-disciplinary environment is vital. During the assessment process, this could be supported by the assessing social worker writing down verbal accounts from the prospective foster carers, but the reality is that these skills are a requirement for the role and it will not be enough to get through the assessment if the foster carer fails to undertake the training, written, and verbal tasks thereafter, which are a mandatory part of fostering in Britain today.

If potential carers have settled in Britain in more recent years, the important police and referee checks will still need to be carried out. The verification of individuals' and families' 
characters and honesty will be more difficult to achieve outside the country, especially if the country of origin is in a state of upheaval due to war or internal conflict. ${ }^{54}$ These factors do present barriers to Muslim foster carers and other ethnicities. It also creates a dilemma for social workers trying to support potential Muslim carers/adopters because the need to verify the applicant's identity and good conduct outside of Britain is as important as ensuring it within this country. The assessing social worker has a duty to the children placed in the care of any foster carer or adopter to ensure comprehensive checks are carried out to minimise the risk of abuse by these carers/adopters to the child(ren) placed in their care. ${ }^{55}$

Mistrust of Social Services by Muslim and ethnic communities is another factor that may create barriers in the recruitment of foster carers and adopters. A Mori poll study revealed:

While two in five members of the general public (43\%) say that 'generally speaking...most people can be trusted', with $48 \%$ taking the contrary view that 'you can't be too careful'; nine per cent reject this simple dichotomy, and volunteer that 'it depends'. Muslims, however, are rather more likely (55\%) to feel that 'you can't be too careful', and much less likely (28\%) to feel 'most people can be trusted', with twice as many, $17 \%$, saying unprompted that it depends. ${ }^{56}$

It will be interesting to find out if the figures have changed since $2010 / 11$ or since the introduction of Prevent which targets primarily Muslims in its quest to identify radicalisation and potential terrorist threats. Further research was undertaken during 2018 by the Muslim Council of Britain (MCB). 'Over the course of 2018/19, the MCB ran a national listening exercise to explore the topic of terrorism, counter-terrorism and Muslim communities ${ }^{57}$ in an effort to understand the effect of this legislation on the Muslim communities in Britain. I envisage it will in some way support the view that a lack of understanding of Islam and specific cultural practices and thinking along ethnicity in general makes the Prevent strategy a potential tool for superficial stereotypical oppression and the 'othering' of British Muslims. This theoretically applies to both children and caregivers. Hypothetically, there could arguably be reasons why Muslim carers are not given more support and encouragement to come forward by governmental agencies. The mantra behind Prevent is integration, and how better to integrate Muslim children than by rearing them in British homes?

\section{THE SHORTAGE OF MUSLIM FOSTERING AND ADOPTING FAMILIES COMING FORWARD}

Although the word 'Islamophobia' was introduced by the Runnymede Trust in their 1997 report on the state of Muslim communities in the UK, it has in fact been around under other guises for many centuries. It is a form of racism based on cultural and religious differences, where criminality, unemployment, etc. are seen through a cultural lens and referred to as cultural fundamentalism..$^{58}$ Critical Race Theory (CRT) has trickled into the UK over the last decade from America mainly through interest in research into academic achievement and the experience of minority racial groups. 'Islam has and continues to be portrayed as inferior, primitive, violent, irrational, oppressive and undemocratic. This is juxtaposed with the West as civilized, reasonable, sophisticated, enlightened, and democratic. ${ }^{59}$ This could be 
seen by exponents of CRT to be part of the powerful white majority's nationalistic othering of a whole religious minority group in the case of Islamophobia.

Unlike the mainstream sociological theories such as those of Freud, Hegel and Marx, 'CRT was inspired by the American civil rights tradition through figures such as Martin Luther King, Jr. and W.E.B. Du Bois, and from nationalist thinkers such as Malcolm X, the Black Panthers, and Frantz Fanon. Being steeped in radical black thought and nationalist thinking, critical race theory advanced theoretical understandings of the law, politics, and American sociology that focused on the efforts of white people (Euro-Americans) to maintain their historical advantages over people of colour. ${ }^{60}$ Now in England, CRT may help to expose a multi-faceted policy which has been hidden under a rhetoric of multiculturalism but which began for Britain centuries ago in the oppression and pillaging of other nations' wealth, cultures, and religions.

Where this is leading? There is a suggestion that as part of the powerful white majority in Britain, there is a permeation from the government level through to the individual consciousness groomed over several hundred years that research into Muslim children and the quality of care they receive is of no intrinsic importance in the overall scheme of things. This could also be levelled at all aspects of social stratification for Muslims and other ethnic minorities. As research is time-consuming and more importantly costly, it could be argued that the irrelevance of Muslim lives, as arguably can be seen by Western activities in the Muslim-majority Middle East and Asia, is a narrative which has been hidden deep into not just the native population in Britain, but also within the psyche of Muslims and other ethnic minorities. ${ }^{61}$

As previously mentioned, there are several barriers concerning the assessment process and Islamic principles which might prevent Muslim foster carers and adopters from coming forward. However, population demographics may also offer some further slant on the problem. Muslim and Sikh families tend to have large families, with many children to care for. ${ }^{62}$ The parents may also live within multi-generational settings with elderly parents to care for also. This arguably could have barriers in terms of capacity to care for further children, especially those experiencing trauma from their pasts. This would apply to foster carers and adopters alike.

Further, research shows that families of Pakistani and Bangladeshi origin tend to live in 'overcrowded homes, which lack basic amenities, and obviously this does not militate in favour of adoption (or fostering) in the view of either prospective parents (foster carers) or for placing agencies. ${ }^{63}$ Indeed the basic requirement to foster or adopt is the need for a spare room. In many Muslim families, sharing bedrooms is part of their culture. Speaking to the Muslim Foster Project, they informed me that Somali families, in particular, think in terms of spare bed, not spare room. The Runnymede Trust's recent research reported that over half of Bangladeshi and Pakistani children live in poverty, ${ }^{64}$ and given that the rates of poverty among Muslims generally are much higher than the average, 'tackling poverty would greatly improve British Muslims' opportunities and outcomes. ${ }^{65}$ If the issue of poverty were addressed, one could argue it would place more Muslims in a position to think about fostering or adoption. 


\section{THE IMPORTANCE OF MATCHING FOR PLACEMENT STABILITY AND MEETING THE NEEDS OF CHILDREN'S IDENTITY}

The ethnicity of looked-after children is predominantly white. $75 \%$ of looked-after children in 31 March 2017 were white, 9\% were of mixed ethnicity, 7\% were black or black British, $5 \%$ were Asian or Asian British, and 3\% were of other ethnic groups. Non-white children appear to be slightly over-represented in the looked-after children population; in particular, children of mixed and black ethnicity. Children of Asian ethnicity are slightly under-represented. ${ }^{66}$ Over the last five years, there have been small increases in the proportions of looked-after children of non-white ethnicity, which likely reflects the increase in the number of unaccompanied asylum-seeking children. ${ }^{67}$ Unfortunately, many local authorities fail to record the child's religion; this must happen in order to assess the true imbalance of Muslim carers to Muslim children in care and those waiting for adoption. The former chairman of Penny Appeal, Aamer Naeem, when speaking about the first guidance ever to come out in Britain on Islamic compatibility with British fostering and adoption laws and policies, commented that 'he hoped to campaign in future for local authorities to record the faiths of those signing up to care for young people, as a way to better understand and address the problem', thus hoping to tackle the poor quality of record-keeping within government agencies involved with the care of children, to better ensure their needs could be monitored and be met. ${ }^{68}$

The 1989 Children Act gave the first formal recognition to issues of 'race' and ethnicity in statutory child care law, requiring local authorities to give due consideration in decision-making for children 'looked after' by them, to 'religious persuasion, racial origin, and cultural and linguistic background. ${ }^{69}$ A late addition to the Act was the requirement that local authorities should recruit Foster Carers with 'regard to the different racial groups to which children within their area who are in need belong, ${ }^{\prime 70}$ to match against ethnicity, race and religion. ${ }^{71}$ This, Kirton argues, was the watershed for acknowledgement of the need to match children within their own ethnic and religious communities.

The Children and Families Act 2014 brought in changes to the Public Law Outline and is aimed at speeding up the adoption process for looked-after children arguably to provide permanence for these children and prevent drift, particularly for those from minority religious, cultural, and ethnic backgrounds where there is a constant shortage of Muslim and minority ethnic adopters. However, the Act, to achieve this outcome, rescinded the requirement to 'match' against ethnicity, race, and religion. ${ }^{72}$ Reported to be in the 'best interests of the child', the Children and Families Act 2014 is religiously, culturally and economically specific and instead of addressing the root cause of poverty through child welfare reforms - which brings many children into care and arguably prevents Muslim and other minority groups to come forward as foster carers, kinship carers, and adopters - chooses to follow neo-liberal economic policies, which stigmatize and blame the poor.

Furthermore, the Children and Families Act 2014 paves the way for the privatisation of adoption, and to allow prospective adopters access to the adoption records. This has yet to be implemented by local authorities, and although the process of allowing individuals access to adoption records is not clear, it plays into the predominately white, middle-class adoption lobbyists' claim to access the children of poor families and ethnic minorities, in particular. 
Interestingly, the 'best interests' mantra is slightly dimmed due to an earlier Ofsted report, Right on Time, which 'found that the most significant cause of adoption delays was not the matching and placement process by adoption agencies and councils but the court process. ${ }^{\prime 73}$ Even so, the retraction of ethnic and cultural matching went ahead.

To understand the real lived experiences of Muslim and ethnic minority children both in foster care and adoption, the question arises as to whether - as one study suggests - Muslim boys fare better in white families. ${ }^{74}$ The data is just not available to answer specific questions concerning the lived experiences of Muslim children in care to ensure that the needs of the children are being met, whether in non-Muslim, Muslim, or other ethnic placements. Unfortunately, the 2014 Children and Family Act saw a reversal of this policy.

\section{THE EXTENDED FAMILY}

Another factor that often comes into play when placing Muslim children is the extended family. In terms of adoption, the rules of Islam 'emphasize to the adoptive family that they are not taking the place of the biological family but are rather serving as trustees and caretakers of someone else's child. Their role is very clearly defined but nevertheless very valued and important. ${ }^{75}$ The Arabic equivalent for adoption is kafāla, which means to take total responsibility for a child, without that child becoming theirs, as opposed to the previously mentioned tabannī, which means to make a child a person's own. The care of an orphan in Islam is more like fostering which can be interpreted by kafāla, but to be absolutely true to Islamic principles, the search for extended family should be a priority where possible.

Even in Britain, the extended Muslim family is usually large, and there are often strong familial ties. In Muslim countries, it is rare for a child to find him/herself totally alone without a single member of their biological family to provide care and shelter for them. The family bonds are very strong and, in addition, Islam places great emphasis on kinship ties; thus, a completely abandoned/orphaned child is rare in Islamic culture. In line with British family court protocol, 'Islamic law places an emphasis on locating a relative to care for the child, and only when this proves impossible does it allow someone outside of the family - and especially outside the community or country - to adopt and remove the child from his or her familial, cultural, and religious roots. This is especially important during times of war, famine, or economic crisis - times when families may be temporarily uprooted or divided. ${ }^{76}$ However, many of the Muslim children come into the British care system due to abuse or neglect issues - see Chart $5 \cdot{ }^{77}$ Although these figures represent all children coming into care, as there are no specific statistics by religion or ethnicity, it does allow some insight into the overall situation.

Children living within an extended family and not with their birth parents have a long history in Britain amongst the native population, and as we have seen within Muslim families, it is part of the culture to take in orphaned children; Islamically, there is a responsibility placed on extended families to do so. In recent British law, 'the requirement to give preference to a placement with a family member was enshrined in the Children Act 1989 (Sec 23 (2) ii) and reinforced by the amendments to the Act in 2011 (Sec 22c). And under the Public Law Outline, the potential of care by kin needs to be considered before care proceedings 
are brought and included in the initial care plan put to the court. These changes, together with the introduction of Special Guardianship Orders, have led to an increase in the use of kinship care. However, while there is much conjecture about the extent and nature of kinship care, there has been little hard evidence. ${ }^{78}$

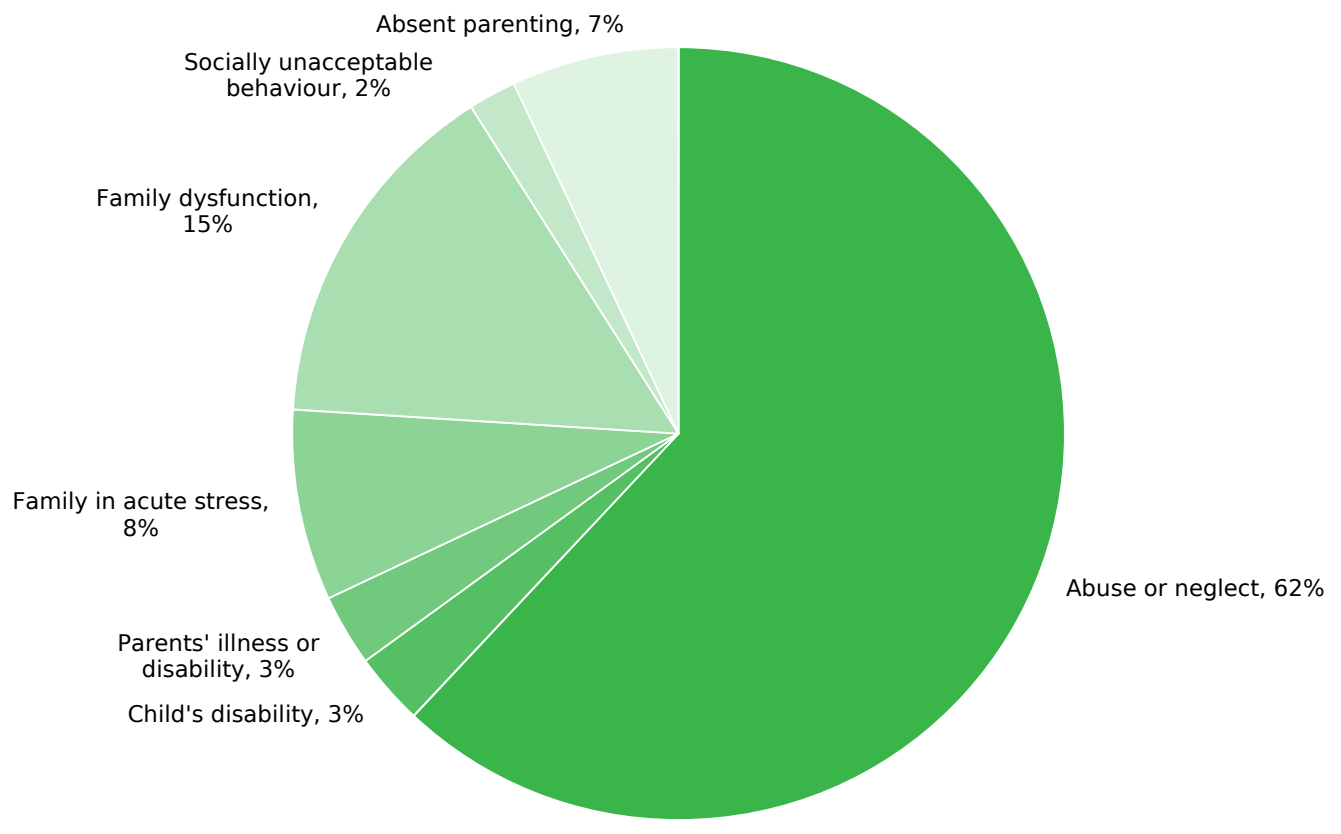

CHART 5: Proportions of looked-after children on 31 March by category of need. England, 2017.

There are many positive reasons to keep children out of the care system and within their own extended family or cared for by close family connections; it would also seem that either fostering or kinship care is the most compatible with Islamic principles. However, it does need to be recognised that the push by the courts and government agencies towards placing children with either extended family or adoptive parents is based on two conflicting aspects in terms of best outcomes for children. ${ }^{79}$ Firstly, to ensure permanency for the children being in their best interests, and, secondly, ensuring the least financial burden on the state as possible. 'The appeal of kinship care to local authorities is that all or most of the costs of supporting the child are shifted away from the local authority and onto, or in some cases returned to, the child's family. Against the background of a rising demand for permanent placements, a range of kinship care arrangements are contributing to the provision of placement options. It is financially far cheaper for local authorities to make, recommend or broker a kinship care arrangement either under 5.17 Children Act 1989 or under a Residence Order granted by the court under s.8 Children Act 1989, than arrange a residential care placement or a family and friends foster care arrangement. ${ }^{\prime 80}$

According to research, 'Kinship care makes an important contribution to placement stability and permanence and its contribution as a placement option is significant. The percentage of children in kinship care placements in England and Wales in March 2005 (12.5\% of the total 'looked-after' figure) is higher than either the $11 \%$ figure for children in children's homes or the $5 \%$ figure for children adopted in March 2005. ${ }^{\circ 1}$ Despite this, 
the resources dedicated to kinship care and kinship carers are lower. ${ }^{82}$ Indeed the push by government agencies for kinship carers to seek special guardianship or residence orders is multi-faceted, but primarily it is to reduce the number of children in local authority care and thus reduce the costs to the state. ${ }^{83}$ It also benefits the children who suffer the stigma of looked-after status and must bi-annually or annually go through medicals, personal educational plan (PEP) meetings and looked-after child (LAC) meetings. Both the child and carers must have regular individual social worker visits every $12 / 6$ weeks respectively, in stable placements ${ }^{84}$ It is a constant imposition into the life of the child and carer, especially with constantly changing workers. It also costs a lot of money, as do the payments to the carers. The meetings, medical, and most other costs end if carers can be encouraged to accept alternative legal care orders.

According to research carried out by Bristol University following the method set out by Dorling and colleagues (2007), who had also used the 2001 census to create a child deprivation index, which identified factors contributing to the risk of deprivation, "England has the most ethnically mixed population of all the UK countries and about a third of kinship children were of minority ethnicity. In relation to children's carers, most of the relatives were white but $15 \%$ of grandparents, about a third of sibling carers and nearly a half of all the 'Other relative carers' were from a minority ethnic background. In comparison with the other UK countries there were more large kinship households (i.e. containing more than 5 people) and this may reflect the greater proportion of minority ethnic kinship families in England. ${ }^{35}$ This research also identified that $71 \%$ of children in kinship care suffered 2 or more indicators of deprivation, and in the general population, the majority of Bangladeshi and Black children suffered multiple deprivations. Although this research is not up to date, it may have revealed part of the reason for the lack of Muslim foster carers and adopters, instead revealing a preference for ethnic families to care for children within the extended family. Further research would be needed to identify the situation concerning that of Muslim families and explore the links found within the Bristol University research to poverty, particularly in families offering kinship care.

\section{SPECIFIC TRAINING REQUIRED FOR NON-MUSLIM FOSTER CARERS AND ADOPTERS CARING FOR MUSLIM CHILDREN}

Nevertheless, there are still cases where Muslim children are not placed with Muslim carers. In these cases, there are interventions that can be done to help overcome some of the challenges surrounding cultural and religious identity. O'Hagan argues that 'cultural identity is a sense of sameness and belonging and is the product of "values, ideas, perceptions and meaning, which have evolved over time". Culture for many migrant families is a way of keeping connected to their past. ${ }^{36}$ Therefore, it could be considered a necessary part of the homogeneous nature of cultural identity for fostered and adopted children, which would make for a strong argument for the need for matching of children to their carers to maintain the internal cohesion of the child. This can be observed in "many Punjabi families, where religion is the key element upon which their identity is nurtured and formed. ${ }^{87}$ Such arguments may equally apply to other immigrant families, whose cultural identity is closely 
linked to their religion. 'The recent arrival of significant numbers of Polish families to the $\mathrm{UK}$, following the expansion of the EU, has seen a considerable increase in attendance at Roman Catholic Churches. Thus, for many migrant people's culture, often expressed through religion, this has great significance for their personal identity. ${ }^{88}$ These issues can be then placed within an overall theoretical consideration of the theory of 'otherness' in relation to our understanding of cultural differences. This needs to be assimilated into the assessment and training of foster carers and adopters, especially those who care for children from different religious and ethnic/cultural backgrounds from the carer.

The training in this area is now coming to be known as 'cultural competency training' but the level of availability for both professionals and foster carers/adopters is unclear across Britain. In Kent, the gateway for the world, the council has published comprehensive policy and guidance in cultural competency (2013), which acts as a benchmark for both professionals and foster carers involved with children from a diverse range of countries, cultures, and religions ${ }^{89}$ However, each local authority and independent fostering and adoption agencies tend to run their own training programmes, or purchase in from outside sources; therefore it is difficult without further research to ascertain who is offering training in what.

To return to training and support of both professionals and foster carers/adopters, from research undertaken in Australia and published in the British fournal of Social Work, it was ascertained that, "in principle, participants in the study agreed it is possible to learn to be culturally competent. ${ }^{30}$ This is an important start to the subject of training. It is also important that the attendees have the capacity to be aware of their own internal messages about differences in general and race, culture, and religion in particular. There are obviously other areas of difference including disability, LGBT, mental illness, etc., which are not within this article's remit. Problems in Harrison and Turner's research (2011) also identified the changing nature of culture; with such a wide range of cultures (especially present in Britain), which cultures to focus on? ${ }^{91}$ So, a question needs to be asked at this point. Should we be talking about cultural competence training or for the purpose of this article, 'training in the care of culturally diverse Muslim children' through Cultural Humility? Perhaps the needs of the foster carers/adopters specifically identified as having Muslim children in their care (or the possibility of such) must be focussed on purely in this area?

The observations made in the study by Harrison and Turner ${ }^{92}$ are identifiable in the Kent County Council's attempt to educate and support their social workers and foster carers to care for the many unaccompanied Muslim asylum-seekers entering through the port of Dover. That said, many of these children may be dispersed rapidly into the care of other local authorities, but all would begin their experience of the British care system at this point.

At this stage, it is not possible to arrive at a definitive answer to this area of investigation without substantial research into the precise needs of the children currently in care and coming into care at this present time. There is a wide variety of cultural and religious differences within the Muslim community. One has to identify the many similarities to structure the training upon, with sub-grouping again looking for similarities within those groups, and so on until the arrival at distinct differences to provide a much-needed and very comprehensive understanding of the many cultures and races, theologies, languages and group experiences that go to make up Muslim children in Britain and in the British care system. This could provide a comprehensive approach not just to the training of professionals and 
carers, but to a greatly enhanced understanding of the specific needs of the children being cared for/adopted. While social work training reflects the need for cultural competence in social work practice as defined by attitudes, knowledge, and skills, in America it also introduces the concept of cultural humility as an additional framework to consider. Cultural Humility emphasises the role of the social worker as a learner in the client-practitioner relationship. Alongside that, cultural humility focuses on empowering the client to be the expert in their own life rather than the subject of a practitioner's accrued knowledge and awareness of cultural information. ${ }^{93}$

\section{AREAS FOR FURTHER RESEARCH AND THE QUESTIONS THESE POSE}

Islam retains a central place in many Muslims' lives; it enriches their sense of identity and belonging and ties them into their communities. 'The importance of religion is even more strongly expressed by Muslim children: 79\% of Muslim 13-14 year olds say religion is "very important" to the way they live their life. Moreover, according to the comparisons over time with the Citizenship Survey, the proportion of Muslim people in Britain who practised their religion increased (from $73 \%$ in 2005 to $79 \%$ in $2009-10$ ), and this rise was particularly evident in the younger (16-29) age group (from 68\% to 80\%). ${ }^{\prime 94}$ These percentages are very high and without further research among Muslim children in care, one can only assume it would be representative of this group also and, if not, it would be equally important to understand why not.

The need for research into the diversity of culture amongst Muslims is another area to feed into tailored training for professionals and carers regarding the care of children. This research and more specific training would also benefit social workers, health professionals, and mental health workers engaging with Muslim families. An area which also requires attention academically is the experience of white Muslim reverts and their children's experience coming into the care system. Indeed, a better understanding of white Muslims may well be relevant if their material resources are more able to offer a home to a Muslim child. Furthermore, it would also be beneficial to have a comparative scrutiny of the reasons behind children from minority and Muslim groups coming into the care system, in comparison with those of white children, and how much Prevent has influenced professionals' decision-making when dealing with Muslim families.

The experiences of unaccompanied asylum-seeking children are a further area requiring urgent research, especially given the recent suicides of three teenagers. The treatment of these children by Home Office immigration also needs to be studied to determine whether there are any oppressive or inhumane policies.

\section{CONCLUSION}

The British government's shift in 2014 away from ethnic/cultural 'matching' was arguably justified by the lack of foster carers and adopters from BAME backgrounds, in particular for children waiting for adoption, which caused the children to languish in care longer 
than their white counterparts. This was done even though research into BAME fostering and adoption has repeatedly found that matching forms a crucial aspect in the long-term success of the majority of BAME placements. It is positive in terms of a sense of belonging to an ethnic/religious group, and it forms part of a child's development and integration in terms of supporting their identity, and protecting them from racist, Islamophobic, and/or religious abuse and cultural isolation.

Studies into meeting the religious/spiritual needs of fostered and adopted children in general are virtually absent, with many local authorities failing to even record the child's religion. Urgent changes must be demanded to include acknowledgement of the child's religion: not only is it part of the child's identity and cultural and ethnic background, but it is also one of the inalienable rights of the parents to decide their child's religion. Thus, as social workers intent on anti-oppressive, anti-discriminatory practice, it is vitally important to uphold and respect parents' and children's religious wishes. However, this is being undermined by a systematic secularisation of social services from child and adult care settings, to education and health.

The central government's motives in removing the requirement to match BAME children with ethnically and culturally compatible families has been argued to be part of cost-cutting, especially where children can be either adopted or moved out of the care system through special guardianship orders or residence orders, which are relatively cost-free to cashstrapped local authorities. Although presented as being 'in the child's best interests', it is a debatable subject and one which requires further research and specifically so.

The analysis shown in the table comparing Islamic principles and British fostering and adoption legislation and policies concludes that particularly in the area of fostering or kinship care, these are highly compatible with Islamic principles. Regarding adoption, there needs to be further research done, especially if Muslim children are being adopted by non-Muslim families. Where they are being adopted by Muslim families, discussion, and possible compromise needs to be agreed upon prior to formal adoption to safeguard the adopted child's paternal lineage (unless the child is at risk of harm). Training for professionals, judges, and adoptees needs to consider the Islamic principles, and changes to the current adoption legal process could be introduced to accommodate the child's lineage, in terms of issuing birth certificates with reference to the birth parents and hyphenating the birth father's name to the adoptive father's. The differences are not so great that, with willingness between the professionals and adoptive parents, compromises cannot be worked out. So, in principle, fostering and adoption are acceptable to Islamic principles and highly recommended.

It is encouraging that researchers from Bristol, Coventry and Oxford Universities in particular, have been working in this area. However these are early studies in the UK and what is not currently known about Muslim children in care and awaiting adoption is so vast that the need to discover, inform and improve the outcomes of Muslim children, and support more Muslims wishing to care for Muslim children is an ongoing challenge. 


\section{NOTES}

1. 'Fostering and Adoption National Statistics', Ofsted (2016/2017), accessed 24 July 2018. <https://www. gov.uk/government/organisations/ofsted/about/statistics>. Fostering and adoption national statistics also available at $<w w w . i c c u k . o r g>$.

2. Islamic Guidance on the Contemporary Practice of Adoption and Fostering in the UK (n.l.: Penny Appeal, 2015) <https://pennyappeal.org/storage/app/media/appeals/Adoption\%2oand\%2oFostering/Adoption\%2oand\%2o Fostering/Islamic\%2oGuide/Final\%2oIslamic\%2oAdoption\%2oand\%2oFostering\%2o-\%2oprint\%2opdf.pdf>. 3. Statistics available on the UK Refugee Council website at <https://www.refugeecouncil.org.uk/latest/ news/5357_latest_immigration_statistics_published/>. Accessed 5 June 2020 .

4. Amelia Gentleman, 'Eritrean Suicides raise alarm about UK treatment of child refugees', in Guardian, 30 July $2018<$ www.theguardian.com/uk-news/2018/jun/17/suicides-raise-alarm-about-uk-treatment-of-childrefugees-eritrean $>$. Accessed 6 Jun 2020.

5. 'Fostering in England 2016 to 2017: main findings', in Ofsted, accessed 24 July 2019 <www.gov.uk/ government/publications/fostering-in-england-1-april-2016-to-31-march-2017/fostering-in-england-2016-to2017-main-findings>.

6. T. Jiva, Unpublished Freedom of Information Returns (Wakefield: Penny Appeal, 2017).

7. 'Children looked after return to 2017 to 2018: guide', in Ofsted, accessed 21 July 2018 <www.gov.uk/government/publications/children-looked-after-return-2017-to-2018-guide>.

8. Ibid.

9. Refugee Council, Asylum Statistics (London: Refugee Council, 2018) <www.refugeecouncil.org.uk/ assets/ooo4/3376/Asylum_Statistics_May_2018.pdf>.

10. Ibid.

11. Amelia Gentleman, 'Eritrean Suicides'.

12. 'National statistics asylum data tables', in GOV.UK, accessed 27 June 2018 <www.gov.uk/government/ statistics/immigration-statistics-april-tojune-2017-data-tables>.

13. Sara Ashencaen Crabtree, Fatima Husain, and Basia Spalek, Islam and Social Work: Culturally Sensitive Practice in a Diverse World, 2nd ed. (Bristol: Policy Press, Bristol 2017), 121.

14. 'Fostering and Adoption National Statistics', Ofsted (2016/2017).

15. Penny Appeal, Islamic Guidance on the Contemporary Practice of Adoption and Fostering in the UK.

16. Department for Education, 'United Nations Convention on the Rights of the Child (UNCRC): how legislation underpins implementation in England' [policy paper], in GOV.UK, published 15 March 2010 <https://www.gov.uk/government/publications/united-nations-convention-on-the-rights-of-the-childuncrc-how-legislation-underpins-implementation-in-england>.

17. Statistics available on the UK Refugee Council website at <https://www.refugeecouncil.org.uk/latest/ news/5357_latest_immigration_statistics_published/>. Accessed 5 June 2020.

18. Sara Ashencaen Crabtree, Fatima Husain, and Basia Spalek, Islam and Social Work, 121. Research cited from Moffat and Thoburn, 2001.

19. David Pitcher and Shabana Jaffar, “To another's house": the experiences of Muslim young people in foster care', Adoption \& Fostering 42, no. 3 (2018): 219-233.

20.A mahram is a close family member of the opposite gender, either biologically or through wedlock, as described in Q. 24:31. All other relatives - including adopted siblings, foster siblings, step-siblings, and cousins - are non-mahram, and hijab between the males and females must be adhered to.

21. Penny Appeal, Islamic Guidance on the Contemporary Practice of Adoption and Fostering in the UK. 
22. S. Cheruvallil-Contractor and S. de Sousa, 'Faith in the Care System: Addressing the Diverse Needs of Children' (paper presented at Second Annual Faith and Peaceful Relations Conference, Coventry, UK, 2017). 23. Q. 2:220; 6:152; 93:6 and 9; 18:82; 89:16-17; 4:36; 2:215; 4:127; 4:6; see also Azislam.com, 'RIGHTS OF ORPHANS IN ISLAM - LAWS', accessed 24 June 2018 <https://azislam.com/rights-of-orphans-in-islam>.

24. Penny Appeal, Islamic Guidance on the Contemporary Practice of Adoption and Fostering in the UK.

25. Ibid.

26. Ibid.

27. James Munby, Family Court Bench Book(n.l.:Judicial College, 2018)<https://www.judiciary.uk/wp-content/ uploads/2016/10/family-court-bench-book-jan-2018.pdf>.

28. Elsbeth Neil, 'Post-adoption contact and openness in adoptive parents' minds: Consequences for children's development', British fournal of Social Work 39, no. 1 (2009), 5-23.

29. F. Hamida, 'Islam and bioethics', in The human rights, ethical and moral dimensions of health care (Strasbourg: Council of Europe Publishing, 1998), 84.

30. Ibid.

31. Paul Michael Garrett, 'Transforming' Children's Services: Social Work, Neoliberalism and the 'Modern' World (New York: McGraw-Hill, 2009).

32. Farah Elahi and Omar Khan, Islamophobia: Still a challenge for us all, ed. Farah Elahi and Omar Khan (n.l.: Runnymede Trust, 2017), 5-12.

33. 'United Nations Convention on the Rights of the Child (UNCRC): How Legislation Underpins Implementation in England', GOV.UK [policy paper], accessed 5 June $2020<$ https://www.gov.uk/government/ publications/united-nations-convention-on-the-rights-of-the-child-uncrc-how-legislation-underpinsimplementation-in-england>.

34. 'Fostering services: national minimum standards', GOV.UK (2011), accessed 5 June $2020<$ https://www. gov.uk/government/publications/fostering-services-national-minimum-standards $>$; 'Adoption: national minimum standards', GOV.UK (2011), accessed 5 June 2020 <https://www.gov.uk/government/publications/ fostering-services-national-minimum-standards>.

35. Q. 2:220, 6:152, 93:6 and 9, 18:82, 89:16-17, 4:36, 2:215, 4:127, 4:6; see also '20 Rights of Orphans in Islam Laws', AZIslam, accessed 22 July 2018 <https://azislam.com/rights-of-orphans-in-islamhttps://azislam.com/ rights-of-orphans-in-islam> (citing Q. 2:220; 6:152; 93:6 and 9; 18:82; 89:16-17; 4:36; 2:215; 4:127; and 4:6).

36. Penny Appeal, Islamic Guidance on the Contemporary Practice of Adoption and Fostering in the UK.

37. D. Kirton, 'Race', Ethnicity and Adoption (Buckingham: Open University Press, 200o), 7; B. Broad, 'Kinship care: What works? Who cares?', Social Work \& Social Sciences Review 13, no. 1: 59-74 < www.researchgate.net/ journal/o953-5225_Social_work_social_sciences_review>.

38. Azislam.com, 'RIGHTS OF ORPHANS IN ISLAM LAWS'; Department for Education, 'Fostering services: national minimum standards'; Department for Education, 'Adoption: national minimum standards'.

39. Penny Appeal, Islamic Guidance on the Contemporary Practice of Adoption and Fostering in the UK.

4o.Adoption records available at <http://www.gov.uk/adoption-records $>$.

41. Ibid.

42. Department for Education, 'Adoption: national minimum standards', Standard 1.

43. Department for Education, 'Fostering services: national minimum standards', Standard 2.1.

44. See the website of the Muslim Foster Network <www.muslimfosternetwork.org.uk>.

45. F. Elahi and O. Khan, Islamophobia - Still a challenge of us all (n.l.: Runnymede, 2017), ch.7.

46.J. T. Selwyn and L. G. Frazer, 'Why are we waiting? The demography of adoption for children of black, Asian and black mixed parentage in England', Child and Family Social Work 10, no. 2 (2005): 135-147. 
47. S. Housee, S, 'What's the point? Anti-racism and students' voices against Islamophobia', fournal of Race Ethnicity and Education 15, no. 1 (2012) < https://www.tandfonline.com/doi/abs/10.1080/13613324.2012.638867>. 48. Steve Bird, 'Government urged to help foster carers spot potential terrorists', in Telegraph 23 September 2017, accessed 10 July 2018 <www.telegraph.co.uk/news/2017/o9/23/government-urged-do-help-fostercarers-spot-potentialterrorists>.

49. Amelia Gentleman, 'Eritrean Suicides'.

50. Muslim Foster Network, accessed 28 July 2018 <https://www.muslimfosternet< work.org.uk/https://www. muslimfosternetwork.org.uk>.

51. Telephone discussion with Muslim Foster Network concerning barriers to fostering, 31 July 2018.

52. N. Luke and J. Sebba, How are foster carers selected? An international literature review of instruments used within foster carer selection (Oxford: Rees Centre, University of Oxford, 2013.).

53. K. Wilson and J. Evetts, 'The Professionalisation of Foster Care', fournal of Adoption \& Fostering 30, no. 1 (2006): 39 .

54. 'Criminal records checks for overseas applicants', in Gov.uk, accessed 15 July 2018 <www.gov.uk/ government/publications/criminal-records-checks-for-overseas-applicants>.

55. Department for Education, 'Fostering services: national minimum standards'; Department for Education, 'Adoption: national minimum standards', last accessed 24 July $2018<$ https://assets.publishing.service.gov. uk/government/uploads/system/uploads/attachment_data/file/192705/NMS_Fostering_Services.pdf>.

56. 'Citizenship Survey, 2010-2011', in UK Data Service, accessed 12 August $2018<\mathrm{http}: / /$ doi.org/10.5255/ UKDA-SN-7111-1>.

57. 'National Listening Exercise', in The Muslim Council of Britain, accessed 15 July $2018<\mathrm{https} / /$ mcb.org.uk/ project/nle/>.

58. S. Housee, 'What's the point? Anti-racism and students' voices against Islamophobia', fournal of Race Ethnicity and Education 15, no. 1 (2012): 101-120.

59. Namita Chakrabarty, Lorna Roberts, and John Preston eds., Critical race theory in England (New York: Routledge, 2014), 1-3.

6o.T. Curry, 'Critical race theory', accessed 24 July $2018<$ www.britannica.com/topic/critical-race-theory>.

61. F. Elahi and O. Khan, Islamophobia: Still a challenge for us all.

62. Lesley Frazer and Julie Selwyn, 'Why are we waiting? The demography of adoption for children of black, Asian and black mixed parentage in England', Child \& Family Social Work 10, no. 2 (2005), 135-147.

63. Ibid.

64. 'Measuring Child Poverty: Implications for Black and minority ethnic families', in Runnymede, accessed 15 July $2018<$ www.runnymedetrust.org/blog/measuring-child-poverty-implications-for-black-and-minorityethnic-families>.

65. Barbara Cohen and Waqas Tufail, 'Prevent and the Normalization of Islamophobia', in Islamophobia: Still a challenge for us all, ed. Farah Elahi and Omar Khan (n.l.: Runnymede, 2017): 41-45.

66. Population figures for children aged under 18 years are taken from the 2018 Nomis official labour market statistics, available at their website at <http://www.nomisweb.co.uk>.

67. 'Children looked after in England (including Adoption)', in GOV.UK, published 31 March $2017<$ www.gov. uk/government/collections/statistics-looked-after children>.

68. '2018 New Guidance aims to dispel myths around fostering and adoption amongst Muslims', in Asian

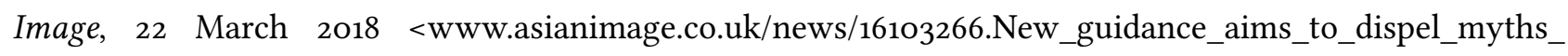
around_fostering_and_adoption_amongst_Muslims/22nd March 2018>. 
69. Text available at The National Archives, last accessed 20 July $2018<$ www.legislation.gov.uk/ukpga/1989/41/ contents>.

70.Ibid. See, in particular, the text of Children Act 1989, Schedule 2(11)(b)).

71. Derek Kirton, 'Race', ethnicity and adoption (Buckingham and Philadelphia: Open University Press, 20oo), 27.

72. Manjit Gheera and Rob Long, Inter-racial adoption (London: House of Commons Library, 2013).

73. 'Exploring delays in adoption: right on time', in Ofsted, published 2 April $2012<$ https://www.gov.uk/ government/publications/exploring-delays-in-adoption-right-on-time>.

74. Sara Ashencaen Crabtree, Fatima Husain, and Basia Spalek, Islam and Social Work, 121.

75. 'Islamic Thoughts and Views regarding Adoption', in ThoughtCo, accessed 17 July $2018<$ www.thoughtco. com/adopting-a-child-in-islam-2003804www.thoughtco.com/adopting-a-child-in-islam-2003804>.

76. Ibid.

77. Department for Education, 'Children looked after return 2017 to 2018: guide', in GOV.UK, accessed 16 July 2018 <www.gov.uk/government/publications/children-looked-after-return-2017-to-2018-guide>.

78. S. Nandy and J. Selwyn, Spotlight on Kinship Care (Bristol: Bristol University, 12011), <www.bristol.ac.uk/ media-library/sites/sps/migrated/documents/execsum.pdf>. Accessed 15 June 2018.

79. Sue Moyers, Elaine Farmer, and Jo Lipscombe, 'Contact with family members and its impact on adolescents and their foster placements', British fournal of Social Work 36, no. 4 (2006), 541-559.

8o.B. Broad, 'Kinship care', in Social Work and Social Sciences Review 13, no.1 (2007), 59-74.

81. Ibid.

82. J. Munby, 'Regina (L and Others) v Manchester City Council, Regina (R and Another) v Same: QBD 28 Sep 2001', in Swarb.co.uk (2001), accessed 26 July $2017<$ https://swarb.co.uk/regina-l-and-others-v-manchestercity-council-regina-r-and-another-v-same-qbd-28-sep-2001>.

83. E. Farmer and S. Moyers, Children placed with family and friends: Placement patterns and outcomes. (Bristol: University of Bristol, 2006).

84. Department for Education, 'Fostering services: national minimum standards', Standard 21.6.

85. Shailen Nandy and Julie Selwyn, 'Kinship care and poverty: using census data to examine the extent and nature of kinship care in the UK', British fournal of Social Work 43, no. 8 (2013), 1649-1666.

86. Kieran O'Hagan, 'Culture, cultural identity, and cultural sensitivity in child and family social work', Child and Family Social Work 4 (1999), 269-282.

87. J. S. Dosanjh and Paul A.S. Ghuman, 'Punjabi childrearing in Britain: Development of identity, religion and bilingualism' Childhood 4, no. 3 (1997), 285-303.

88. Graeme Simpson and Brian Littlechild, 'International aspects of social work with children, young people and families', Introducing international social work (2009), 45-59.

89. Kent County Council, Cultural Competence in Kent. Policy and Guidance. <http://kentchildcare. proceduresonline.com/pdfs/culture_comp_policy.pdf>. (2013) Accessed 1 August 2018.

90.Gai Harrison and Rachel Turner. 'Being a "culturally competent" social worker: Making sense of a murky concept in practice', The British fournal of Social Work 41, no. 2 (2011), 333-350.

91. Ibid., 343 .

92. Ibid., 330-350.

93. Robert M. Ortega and Kathleen Coulborn, 'Training child welfare workers from an intersectional cultural humility perspective: a paradigm shift', Child Welfare 9o, no. 5 (2011), 27-49.

94. Robert Rutherford, 'Race, Religion and Equalities: A report on the 2009-10 Citizenship Survey', in GOV.UK, accessed 30 July 2018 <https://webarchive.nationalarchives.gov.uk/20120919214026/http:/www. communities.gov.uk/documents/statistics/pdf/2056245.pdf>. 